\title{
Environmental Corruption Prevention Policies Through Independent Agencies
}

\author{
Mirnawanti Wahab ${ }^{1}$, Rizki Ramadani ${ }^{2}$ \\ ${ }^{1}$ Universitas Muslim Indonesia, Indonesia, \\ E-mail:mirnawanti.wahab@umi.ac.id \\ ${ }^{2}$ Universitas Muslim Indonesia, Indonesia, \\ E-mail: rizkiramadani@umi.ac.id
}

Submitted: February 10, 2021; Reviewed: March 1, 2021; Accepted: April 14, 2021

\begin{tabular}{|c|c|}
\hline Article Info & Abstract \\
\hline $\begin{array}{l}\text { Keywords: } \\
\text { Environmental Corruption, } \\
\text { Independent Agency, Policy, and } \\
\text { Supervision. } \\
\text { DOI: } \\
\text { 10.25041/fiatjustisia.v15no4.2245 }\end{array}$ & $\begin{array}{l}\text { This article aims to explain the patterns of } \\
\text { corruption in the environmental sector } \\
\text { (environmental corruption) and the possibility for } \\
\text { Independent agencies to address them. Also, to } \\
\text { initiate a better policy and supervision against } \\
\text { environmental corruption in Indonesia. The } \\
\text { research was carried out based on the normative } \\
\text { legal method (library research) towards secondary } \\
\text { data using a statutory, conceptual, and comparative } \\
\text { approach. The results show that the main pattern of } \\
\text { environmental corruption involves corrupt actors in } \\
\text { bureaucratic institutions that cause weak } \\
\text { environmental policies and supervision. The benefit } \\
\text { of Independent Agencies with structural and } \\
\text { personnel independence is expected to fill the gap in } \\
\text { the old bureaucratic management and reduce } \\
\text { corruption. The regulatory power of such agencies } \\
\text { can also set more stringent environmental policy } \\
\text { and supervision. Thus, there needs to be institutional } \\
\text { reform in the environmental authorities for future } \\
\text { policies by establishing an independent agency. The } \\
\text { new agency must also have the power to formulate } \\
\text { and enact policies in environmental management } \\
\text { and give them authority to investigate and impose } \\
\text { sanctions. We also recommend compiling a national } \\
\text { strategic program in the form of work synergy } \\
\text { between independent agencies in the environmental } \\
\text { and anti-corruption sector. }\end{array}$ \\
\hline
\end{tabular}

\section{A. Introduction}

In the Indonesian context, the high number of corruption cases is an old issue that cannot be fully resolved. Although a series of efforts have been 
made to reduce the number of corruption, they have not completely eradicated the corruption that has long been rooted in the bureaucracy and society. ${ }^{1}$ Throughout 2018, the Corruption Eradication Commission carried out at least 30 arrests targeting ministries, DPR members, and regional heads. In the same year, state losses due to corruption reached Rp. 9.29 trillion. The KPK also receives around 7,000 letters per year from the public reporting allegations of corruption. ${ }^{2}$ During the first semester of 2020, Indonesia's Corruption Watch (ICW) recorded total state losses from corruption cases amounting to IDR 39.2 trillion. During the last year, the number of corruption cases also resulted in the fall of the Corruption Perception Index (CPI) in Indonesia from the score of 40 in 2019 to 37 in 2020, as released by Transparency International. ${ }^{3}$

In terms of corruption in the environmental sector, since 2009, Human Rights Watch has reported the impact of corruption crimes in the forestry sector, which cause an average of USD 2 billion in material losses per year. ${ }^{4}$ The KPK studies on the forestry sector and commercial wood production up to 2014 also showed that the state continued to suffer losses every year due to logging activity and timber production, almost eighty percent of which were not recorded by the Ministry of Environment. ${ }^{5}$ Whereas, according to law, those are counted as the theft of state assets classified as corruption. In 2018, the KPK also recorded potential losses in the mineral and coal sector from underpaying taxes Rp. 15.9 trillion, this amount does not include losses from maladministration and flawed licensing system which reached Rp. 28.5 trillion.

In addition to material losses, corruption also correlates with a decline in environmental quality. Several studies have shown that large amounts of corruption impact weak environmental regulations, leading to increased environmental exploitation and decreased environmental quality. ${ }^{6}$ Based on the Environmental Performance Index (EPI) 2020, by using 32 performance

\footnotetext{
${ }^{1}$ Muh Rinaldy Bima and Rizki Ramadani, "Position of Supervisory Board Organ and Its Implications for the Institutional Corruption Eradication Commission," Law Reform 16, no. 2 (2020): 179-97, https://doi.org/10.14710/lr.v16i2.33770.

2 Dylan Aprialdo Rachman, "Kerugian Negara Akibat Korupsi Capai Rp. 929 Triliun," Kompas.com, 2019.

${ }^{3}$ Wardhany Tsa Tsia, "Crowded Criticism Corruption Perception Index Score in Indonesia Is Dropping," Voice Of Indonesia, 2021, https://voi.id/en/berita/29720/crowded-criticismcorruption-perception-index-score-in-indonesia-is-dropping.

${ }^{4}$ Human Rights Watch, Indonesia; "Wild Money”; The Human Rights Consequences of Illegal Logging and Corruption in Indonesia's Forestry Sector (New York: HRW, 2009).

5 Direktorat Penelitian dan Pengembangan (Kedeputian Bidang Pencegahan), "Mencegah Kerugian Negara Di Sektor Kehutanan Sebuah Kajian Tentang Sistem Penerimaan Negara Bukan Pajak Dan Penatausahaan Kayu," Komisi Pemberantasan Korupsi, 2015, https://acch.kpk.go.id/images/tema/litbang/pengkajian/pdf/Laporan-PNBP-Kehutanan-KPKreport-web.pdf.

${ }^{6}$ Heyin Chen et al., "The Impact of Environmental Regulation, Shadow Economy, and Corruption on Environmental Quality: Theory and Empirical Evidence from China," Journal of Cleaner Production 195 (2018): 200-214, https://doi.org/10.1016/j.jclepro.2018.05.206. 328
} 
indicators across 11 issue categories, the EPI placed Indonesia as the $116^{\text {th }}$ rank from 180 countries on environmental health and ecosystem vitality. ${ }^{7}$ Further below Singapore, whose score is at 39th place, Malaysia is in 68th position. If the results of this environmental index are juxtaposed with Indonesia's corruption perception index, the assumption that "corruption causes environmental quality to deteriorate" becomes very logical.

As stated by Winbourne, environmental corruption may occur across many transactions, starting from bribery and cronyism on the level of developing national policy, embezzlement in implementing environmental programs, bribery in issuing permits and licenses, including collecting "rents" while enforcing environmental policies. ${ }^{8}$ This statement is coherent with the results of the public sector integrity survey conducted by the Corruption Eradication Commission (KPK), where the licensing process is the most vulnerable aspect to the practice of corruption. ${ }^{9}$ Corruption cases were also dominated by local government officials at the provincial and district/city levels. Among the several existing modes of corruption, bribery is the most frequent occurrence in environmental corruption. ${ }^{10}$

This study examines environmental corruption from the constitutional law perspective and the theory of independent state institutions as an analysis point. For this reason, this article addresses three main questions as follows: first, what is the pattern that is reflected in environmental corruption? Second, can independent agencies play a role in closing the loopholes for environmental corruption? Third, what are the optimal policies and supervision to fight environmental corruption?

\section{B. Discussion}

\section{The Patterns of Environmental Corruption}

The World Bank defines corruption as "the abuse of public power for private gain", ${ }_{11}$ and acknowledges that corruption is one of the greatest obstacles to economic and social development. Several other experts have also

\footnotetext{
${ }^{7}$ Environmental Performance Index, "Global Metrics for the Environment: Ranking Country Performance on Sustainability Issues," Yale Center for Environmental Law \& Policy, 2020, https://epi.yale.edu/downloads/epipolicymakersummaryr11.pdf.

${ }^{8}$ Svetlana Winbourne, "Corruption and the Environment" (Washington, D.C., 2020).

${ }^{9}$ Fauziah Rasad, "Korupsi Dan Hak Asasi Manusia Dalam Sektor Kehutanan," Jurnal HAM 9 , no. 2 (2018): 121-38, https://doi.org/10.30641/ham.2018.9.121-138.

${ }^{10}$ Komisi Pemberantasan Korupsi, "Laporan Tahunan Komisi Pemberantasan Korupsi Tahun 2014" (Jakarta, 2014).

${ }^{11}$ Sofik Handoyo and Fury Khristianty Fitriyah, "Control of Corruption, Regulatory Quality, Political Stability, and Environmental Sustainability: A Cross-National Analysis," Journal of Accounting Auditing and Business 1, no. 2 (2018): 28-38, https://doi.org/10.24198/jaab.v1i2.18344.
} 
defined corruption. Rose Ackerman ${ }^{12}$ For example, classify corruption into three kinds of dimensions, economic, cultural, and political dimensions. Corruption in the economic dimension is described as a symptom of state maladministration. The institutions that are supposed to regulate relations between the state and its citizens are used for their benefit. In the cultural dimension, corruption is interpreted as a tradition of giving bribes, and gifts which others refer to as corrupt. Meanwhile, in the political dimension, corruption is described as corrupt behavior by government actors who 'have an affair' with private parties.

However, as Petter Langseth wrote, there is no single definition of corruption representing its full, comprehensive, and universal understanding. ${ }^{13}$ Such efforts will limit the definition of corruption, which can be very broad or specific, depending on the systems and traditions that apply in each society and country. This is also the basis for that in consideration of the United Nations Convention against Corruption. It was agreed not to limit the meaning of corruption to one general definition but to only mention the types of acts categorized as corruption. ${ }^{14}$ The offenses mandated by the UN Convention include the active and passive bribery of national public officials; active bribery of a foreign or international public official; money laundering; and embezzlement, misappropriation, or other diversions of property by a public official, including active and passive bribery in the private sector and trading in influence. ${ }^{15}$

In Indonesia, the Corruption Eradication Law classifies corruption into seven groups, namely: (1) detrimental to state finances (enriching oneself or abusing authority to harm state finances); (2) bribery; (3) gratuities; (4) embezzlement in office; (5) extortion; (6) fraudulent acts; and (7) conflicts of interest. Such acts of corruption can occur in various sectors, including the environmental sector or termed 'environmental corruption'. Although there is no specific definition of this term, based on the annual review prepared by Tacconi and Williams, it is known that the type of corruption is in the Environmental and Resources Management (ERM) sector. ERM corruption is then divided into certain sectors such as corruption in the extractive industries (minerals, oil, and gas), irrigation, agriculture, forestry, fisheries, and conservation activities. ${ }^{16}$

\footnotetext{
${ }^{12}$ Susan Rose Ackerman, Korupsi Dan Pemerintahan Sebab Akibat Dan Reformasi (Jakarta: Pustaka Sinar Harapan, 2006).

${ }^{13}$ Arthur Shacklock, Fredrik Galtung, and Charles Sampford, Measuring Corruption, 1st ed. (London: Routledge, 2016).

${ }^{14}$ Luca Tacconi and David Aled Williams, "Corruption and Anti-Corruption in Environmental and Resource Management," Annual Review of Environment and Resources 45 (2020): 30529, https://doi.org/10.1146/annurev-environ-012320-083949.

${ }^{15}$ Organization for Economic Co-operation and Development (OECD), Corruption: A Glossary of International Criminal Standards (Paris: OECD, 2007).

16 Tacconi and Williams, "Corruption and Anti-Corruption in Environmental and Resource Management." 
There is a close relationship between the variables of corruption and environmental policies with the increasingly severe environmental damage, from a study conducted by Damania et al. ${ }^{17}$, It can be seen that there is a clear correlation between the level of government corruption and the flexibility of policies in the environmental sector. In principle, it is said that: the lower the corruption at the government level, the tighter the environmental policies will be. In other research, who analyzed the relationship between corruption and political instability also concluded the same thing, that corruption could reduce the strictness of regulations in the environmental sector. Thus, it can be said that corruption has contributed greatly to weak policies and supervision in the environmental sector.

Weak policies that are mainly open to investment and business interests will further facilitate environmental damage. In this case, the environmental aspect is more often the second priority after investment and economic interests. ${ }^{18}$ This statement is not a mere assumption. Several previous studies have shown a positive correlation between weak and business-oriented environmental policies and the high level of environmental damage. The research conducted by Chen et al. ${ }^{19}$ For example, shows a relationship between the hidden informal economy sector (shadow economy) and bad environmental policies on high environmental pollution in China. The more corrupt government officials, the weaker environmental policies will be, resulting in higher pollution and environmental pollution. In another study conducted by Sinha et al. ${ }^{20}$ Brazil, Russia, India, China, and South Africa (BRICS), and 11 other countries between 1990-2017, shows that much corrupt behavior has increased environmental damage by reducing the use of renewable energy. However, it is also found that corruption increases fossil energy consumption, which harms the environment.

It is also found that there is a tendency that environmental corruption is more prone to occur in countries whose development is developing with bureaucratic institutional systems. ${ }^{21}$ Bureaucracy here is defined as a state institutional system and its administration with a complex, significant, and hierarchical arrangement or levels. It is well known that this kind of

\footnotetext{
${ }^{17}$ Richard Damania, Per G. Fredriksson, and John A. List., "Trade Liberalization, Corruption, and Environmental Policy Formation: Theory and Evidence," Journal of Environmental Economics and Management 46, no. 3 (2003): 490-512, https://doi.org/10.1016/s00950696(03)00025-1.

${ }^{18}$ Herry Purnomo et al., "Politik Ekonomi Kebakaran Hutan Dan Asap Di Indonesia," Center for International Forestry Research, 2015, https://forestsnews.cifor.org/30905/politik-ekonomikebakaran-hutan-dan-asap-di-indonesia?fnl=en.

${ }^{19}$ Heyin Chen et al., "The Impact of Environmental Regulation, Shadow Economy, and Corruption on Environmental Quality: Theory and Empirical Evidence from China."

${ }^{20}$ Avik Sinha et al., "Impact of Corruption in the Public Sector on Environmental Quality: Implications for Sustainability in BRICS and next 11 Countries," Journal of Cleaner Production 232 (2019): 1379-93, https://doi.org/10.1016/j.jclepro.2019.06.066.

${ }^{21}$ Sinha et al.
} 
government bureaucratic model is a vulnerable loophole for corruption which can occur at every level of government, like the central and regional levels. ${ }^{22}$ This is due to the old bureaucratic pattern, which still relies on actors with great authority, so they are vulnerable to abuse. Also, as mentioned by Nagara et al. ${ }^{23}$ it is not uncommon for officials in the bureaucracy to face conflicts of interest or structural problems such as power intervention from higher government elites and other interest groups in the corruption network such as political parties and business circles.

\section{Figure 1. The Patterns of Environmental Corruption}

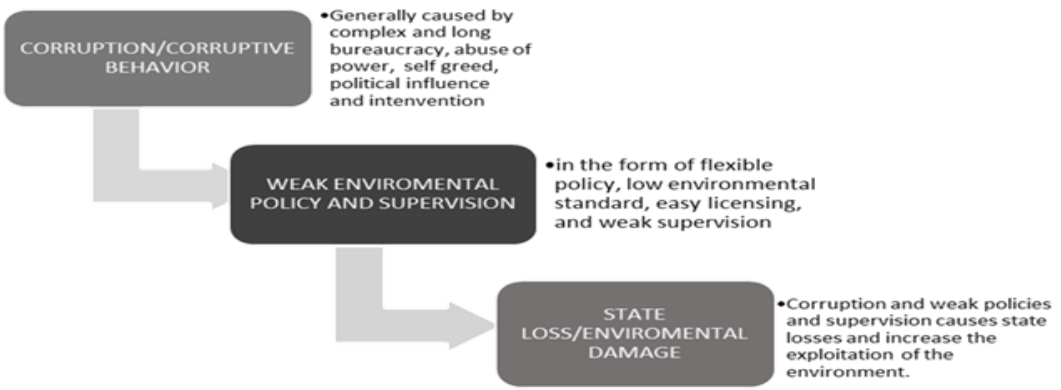

Source: Author's Processed result, 2020.

Based on figure 1, corruption in the environmental sector can be described as follows: first, there is corrupt behavior by the government or bureaucratic officials in the environmental sector who use their authority for personal gain. Second, this corrupt behavior causes policies and supervision in the environmental sector to become loose, business-oriented, and weak environmental law enforcement in general. Third, inadequate policies and supervision have resulted in increased environmental damage and pollution. Thus, state losses come from acts of corruption and environmental damage due to weak supervision by the government.

In the case of Indonesia, the environmental corruption pattern also mentioned by Muslihudin et al. as: ${ }^{24}$ 1) Provision of licensing from the regional head to the businessmen in the form of rewarded bribes from the entrepreneurs to smooth the business licensing. 2) Corruption in the Environmental Impact Analysis (EIA) process, in the form of bribery to get

\footnotetext{
22 Kisno Hadi, "Korupsi Birokrasi Pelayanan Publik Di Era Otonomi Daerah," Jurnal Penelitian Politik 7, no. 1 (2016): 51-70, https://doi.org/10.14203/jpp.v7i1.512.

${ }^{23}$ Grahat Nagara et al., "Persoalan Struktural Dalam Politik Penegakan Hukum Sumber Daya Alam Dan Lingkungan Hidup," Integritas: Jurnal Antikorupsi 5, no. 2-2 (2020): 65-74, https://doi.org/10.32697/integritas.v5i2-2.483.

${ }^{24}$ Muslihudin Muslihudin et al., "Relationship between Environmental Damage and Corruption Cases in Indonesia," E3S Web of Conferences 73 (2018): 1-5, https://doi.org/10.1051/e3sconf/20187302011. 
the recommendations for action plans. The corruption takes the form of collusion between the project owner and the compilers of the EIA and the EIA assessment commission to be more favorable to their interests. 3) Corruption by the Regional Head collects money against all entrepreneurs who apply for EIA.

Law No. 32/2009 On protection and management of the environment has set several requirements that must be met before issuing a license and the commencement of any environment-related activity, including spatial planning, environmental quality standards, environmental impact analysis, and licensing. However, despite all these standards and prerequisites, pollution and corruption still occur in Indonesia. ${ }^{25}$ This shows that existing regulations have not been balanced with honest and independent government actors and law enforcers. Thus, two main problems can be drawn in the pattern of environmental corruption in general, namely: first, the lack of integrity and independence of officials in a fat bureaucratic structure, and second, weak policies and supervision in the environmental sector.

\section{The Concept of Independent Agencies}

Law No. 32/2009 on environmental protection has set several requirements that The emergence and existence of the Independent agencies is an interesting and important thing to observe. This phenomenon occurs nationally during the transition to democracy in Indonesia and globally, which has emerged alongside the new wave of democratization worldwide. ${ }^{26}$ Public service affairs, which the central/executive agency initially monopolized, were then separated and scattered into various types of independent state agencies, which are commonly called "Independent agencies/bodies". ${ }^{27}$ Such institutions include the Federal Trade Commission in the United States, the Commission des Operations de Bourse in Italy, or The Commissions for Racial Equality in the UK. ${ }^{28}$

Some scholars in the United States and Europe have tried to draw clear definitions of an independent agency. Funk and Seamon stated that one category of the institution is often considered outside the executive branch of power called "Independent regulatory agencies". They further elaborate that "independent" means certain characteristics that insulate the agency from

\footnotetext{
${ }^{25}$ Sukanda Husin and Hilaire Tegnan, "Corruption Eradication within the Protection of the Environment in Indonesia," Asian Journal of Water, Environment and Pollution 14, no. 4 (2017): 99-108, https://doi.org/10.3233/AJW-170040.

${ }^{26}$ Koen Verhoest et al., Autonomy and Control of State Agencies: Comparing States and Agencies, 1st ed. (London: Palgrave Macmillan, 2010), https://doi.org/10.1057/9780230277274.

${ }^{27}$ Rizki Ramadani, "Lembaga Negara Independen Di Indonesia Dalam Perspektif Konsep Independent Regulatory Agencies,” Jurnal Hukum Ius Quia Iustum 27, no. 11 (2020): 169-92, https://doi.org/10.20885/iustum.vol27.iss1.art9.

${ }_{28}$ Jimly Asshiddiqie, Pengantar Ilmu Hukum Tata Negara, 5th ed. (Jakarta: PT Raja Grafindo Persada, 2015).
} 
control by the president, where normal executive agencies are subject. ${ }^{29}$ Other scholars such as Knapp and Meny define Independent agencies as independent bodies with a regulatory and supervisory function. ${ }^{30}$ This aspect of independence and regulatory authority is also emphasized by Gillardi, who states that IRAs are a public organization with regulatory powers that are neither elected by the people nor directly managed by elected officials such as the president. ${ }^{31}$

An institution could be recognized as an independent agency if it is not under the president's direct control (presidential control), where the other institutions such as ministries are subject to. Furthermore, Funk and Seamon provide the following characteristic of the independent agencies: ${ }^{32}$ (1) They are headed by multi-member groups, rather than a single agency head; (2) no more than a simple majority of these members may come from one political party; (3) the member of the group has fixed, staggered terms, so that their terms do not expire at the same time; and (4) they can only be removed from their position for "cause", unlike most executive officials, who serve at the pleasure of the president.

The above characteristics can be seen within the independent agencies in Indonesia, which is institutionalized through such agencies' regulation or enabling act. For example, Law No. 30 of 2002 Jo. Law No. 19 of 2019 concerning the second revision of Corruption Eradication Corruption (KPK). An analysis of the institutional aspects of the KPK as the independent agency can be seen in the following table:

\footnotetext{
${ }^{29}$ Rizki Ramadani and Andika Prawira Buana, "The Needed but Unwanted Independent Regulatory Agencies: Questioning Their Legitimacy and Control in Indonesia," in Proceedings of the 2nd International Conference of Law, Government and Social Justice (ICOLGAS 2020) (Dordrecht: Atlantis Press, 2020), 674-84, https://doi.org/10.2991/assehr.k.201209.351.

${ }^{30}$ Yves Mény and Andrew Knapp, Government and Politics in Western Europe: Britain, France, Italy, Germany (Oxford: Oxford University Press, 1993).

${ }^{31}$ Fabrizio Gilardi, Delegation in the Regulatory State: Independent Regulatory Agencies in Western Europe (Cheltenham: Edward Elgar Publishing, 2009).

${ }^{32}$ William F. Funk and Richard H. Seamon, Administrative Law: Examples and Explanations (New York: Aspen Publishers, 2009). 
Table 1. The Characteristics of KPK As Independent Agency

\begin{tabular}{|c|c|c|}
\hline NO & INDEPENDENCE ASPECTS & ARTICLE IN KPK LAW \\
\hline 1 & $\begin{array}{l}\text { Headed by multi-member groups, } \\
\text { rather than a single agency head }\end{array}$ & $\begin{array}{l}\text { Article } 21 \text { (1) no. } 3 \text { The } \\
\text { Chairperson of the Corruption } \\
\text { Eradication Commission consist } \\
\text { of } 5 \text { (five) Members of the } \\
\text { Corruption } \\
\text { Commission }\end{array}$ \\
\hline 2 & $\begin{array}{l}\text { No more than a simple majority of } \\
\text { these members may come from one } \\
\text { political party }\end{array}$ & $\begin{array}{l}\text { Article } 29 \text { To be appointed as the } \\
\text { Chairperson of the Corruption } \\
\text { Eradication Commission must } \\
\text { meet the following } \\
\text { requirements: ... h. does not } \\
\text { become an administrator of a } \\
\text { political party }\end{array}$ \\
\hline 3 & $\begin{array}{l}\text { The member of the group has fixed, } \\
\text { staggered terms }\end{array}$ & $\begin{array}{l}\text { Article } 34 \text { The Chairperson of } \\
\text { the Corruption Eradication } \\
\text { Commission shall hold office for } \\
4 \text { (four) years and may be re- } \\
\text { elected only for one term }\end{array}$ \\
\hline 4 & $\begin{array}{l}\text { Can only be removed from their } \\
\text { position for "cause" }\end{array}$ & $\begin{array}{l}\text { Article } 32 \text { (1) The Chair of the } \\
\text { Corruption Eradication } \\
\text { Commission stops or is } \\
\text { dismissed because: a. die; b. } \\
\text { term of office ends; c. be } \\
\text { accused for committing a crime; } \\
\text { d. unable to remain permanently } \\
\text { or continuously for more than } 3 \\
\text { (three) months unable to carry } \\
\text { out their duties; e. resign; or f. be } \\
\text { subject to sanctions under this } \\
\text { Law. }\end{array}$ \\
\hline
\end{tabular}

Source: Author's Processed Results, December 2020.

With the institutional concept and design described above, the independent agency model has several advantages over ordinary state institutions such as executive agencies or ministries. The multi-member leadership model (commissioners) with the collegial collective system can make it challenging to implement the agency's duties and decisions. Fixed-term office with staggered terms also guarantees independence for members and the leaders from politicization and external interference. So that in general, the independent agency has an institutional design that guarantees and protects the functional, structural, and personnel independence of its actors, including against the possibility of corruption, collusion, and nepotism.

\section{Independent Agencies Performance in Anti-Corruption and Environmental Sector}

Corruption mostly thrives under conditions of secrecy and power imbalances. Weak institutions increase the likelihood of corruption because the actors do not have incentives to act cleanly and are not constrained from 
such behavior because mechanisms ensuring transparency, participation, accountability, and integrity are missing. ${ }^{33}$ In the case of Indonesia, most of the independent agencies were formed after the reform era to reform old state institutions with poor performance or corruptive behavior. For example, independent agencies such as the Judicial Commission (KY) were formed to balance and supervise the judicial power has been known for decades as a hotbed of corruption, collusion, and nepotism. Likewise, the Corruption Eradication Commission (KPK) was intended to become a super body and trigger mechanism for eradicating corruption, all because the police and prosecutors, as anti-corruption law enforcers, often become corruptors themselves. ${ }^{34}$

At this point, these agencies gained high trust from the public because of their independent and autonomous performance. In general, they have what is called structural and functional independence. Structural independence refers to the constitutional position of an independent agency as a new branch of government in a new separation of powers system. ${ }^{35}$ These agencies are not under the executive or legislative branch but are still within the check and balance principle framework. This can guarantee their position from political intervention and subordination. Apart from the KPK, these institutions are the General Election Commission (KPU), The National Human Rights Commission (Komnas HAM), etc. Functional independence refers to autonomy in carrying out duties and powers without intervention from any parties. This aspect has also been widely institutionalized in the regulations or enabling act of the agency such as KPK (Law No 32 year 2002 jo. 19 year 2019), KPU (Law No. 15 Year 2011), and KY (Law No. 18 Year 2011). These two aspects of independence can provide guarantees for a more transparent and accountable public service delivery.

It can be said that the public has a greater expectation of these agencies rather than the government itself. This is shown, for example, by a survey from the Indonesian Survey Institute (LSI) in 2019 of 1,220 respondents. The results show that the Corruption Eradication Commission (KPK) is the most trusted institution by the public with a presentation of $84 \%$, followed by the president $(79 \%)$, the police $(72 \%)$, the Courts $(71 \%)$, the DPR $(61 \%)$, and Political Parties. (53\%). These results contrast with other surveys from LSI on trends in public perceptions of democracy, corruption, and intolerance. As a result, the police, courts, and civil servants are categorized as institutions with

\footnotetext{
${ }^{33}$ Halvor Mehlum, Karl Moene, and Ragnar Torvik, "Cursed by Resources or Institutions?," World Economy 29, no. 8 (2006): 1117-31, https://doi.org/10.1111/j.1467-9701.2006.00808.x. ${ }^{34}$ Rizki Ramadani and Moch Andry Wikra Wardhana Mamonto, "Legalitas Sanksi Pidana Pencabutan Hak Politik Bagi Terpidana Korupsi: Perspektif Hak Asasi Manusia," Petitum 7, no. 2 (2019): 63-71, https://doi.org/10.33096/substantivejustice.v1i2.18.

${ }^{35}$ Bruce Ackerman, "The New Separation of Powers," Harvard Law Review 113, no. 3 (2000): 633-729, https://doi.org/10.2307/1342286. 
a high corruption index. ${ }^{36}$ The presence of the KPK in the last 15 years is also considered to have made a positive contribution through strict enforcement of major corruption cases, arresting more than 1,000 public officials with a success rate of more than $75 \%$, monitoring of law enforcement efforts in corruption cases, and public awareness in instilling a spirit of integrity. ${ }^{37}$

Concerning the environment, the KPK, since 2010, has launched the natural resource sector and energy security as one of the focus areas for eradicating corruption in the KPK's 2011-2015 strategic plan. Based on the 2014 KPK Performance Accountability Report, there were several efforts by the KPK in handling cases of corruption in natural resources. These efforts were made by the KPK, among others, through monitoring action plans in forest management, licensing natural resources, and coal mining policies. There have also been many studies on forestry, fishery, and mineral and coal systems, including investigations and prosecutions of 18 corruption cases in the natural resources sector by $2014 .{ }^{38}$ The results of this performance gained a quite high appreciation and trust from the community. ${ }^{39}$

The key to the success of an independent institution such as the KPK lies in guaranteeing the institution's independence and carrying out its duties with the principle of transparency, accountability, and civil society participation. This is rarely found in the context of government bureaucracy. Also, many independent agencies are given constitutional authority by the legislature (by law) to exercise power independently. These federal agencies practically carry out special functions of government that Funk and Seamon can characterize as quasi-legislative, quasi-executive, quasi-judicial, or a combination of these three functions. ${ }^{40}$

An example of such an agency in the environmental sector is the Environmental Protection Agency (EPA) in the United States, which specializes in protecting environmental pollution. The history of the EPA began In early 1970 due to heightened public concerns about deteriorating city air, natural areas littered with debris, and urban water supplies contaminated with dangerous impurities. President Nixon responded by creating a council to consider organizing federal government programs designed to reduce pollution. Those programs could efficiently address the goals laid out in his

\footnotetext{
${ }^{36}$ Indra Komara, "Survei LSI Polisi, Pengadilan Dan PNS Instansi Paling Korup," Detiknews, 2018, https://news.detik.com/berita/d-4227042/survei-lsi-polisi-pengadilan-dan-pns-instansipaling-korup.

37 Wawan Suyatmiko and Lvin Nicola, "Inisiatif Penguatan Lembaga Antikorupsi Indonesia: Komisi Pemberantasan Korupsi 2015-2019," Tranparancy International, 2018 , https://ti.or.id/wp-content/uploads/2019/07/FINAL-Bahasa-ACA-Assessment-Report_TII.pdf. ${ }^{38}$ Komisi Pemberantasan Korupsi (KPK), “Laporan Akuntabilitas Kinerja KPK 2014”' (Jakarta, 2014).

${ }^{39}$ Listyo Yuwanto, “Kinerja Penanganan Tindak Pidana Korupsi Sumber Daya Alam Dan Kcayaan Terhadap Komisi Pemberantasan Korupsi," Jurnal Integritas 2, no. 1 (2016), https://doi.org/10.32697/integritas.v2i1.137.

${ }^{40}$ Funk and Seamon, Administrative Law: Examples and Explanations.
} 
message on the environment. The president sent to Congress a plan to consolidate many environmental responsibilities of the federal government under one agency, a new Environmental Protection Agency. ${ }^{41}$

EPA has regulatory power since it can set rules to prohibit communities from destroying wetlands. The EPA also conducts investigations on those suspected of violating these rules. If someone has been determined to violate them, the EPA can impose sanctions in the form of several fines. Thus it also has quasi-judicial authorities. Base on this fact, Funk and Seamon said, "In a sense, EPA acts like a legislature, a police officer, and a court all rolled into one." 42

The federal government, especially Congress, has given the EPA considerable powers in carrying out its function to maintain environmental health. There are about 33 laws regarding the environment that intersect with the functions and duties of the EPA and 14 other regulations related to regulatory processes. ${ }^{43}$ In general, the EPA not only sets regulations and standards for environmental pollution but can also ban permits for the construction of major new and/or modified sources of a pollutant, even imposing its federal plan and regulations to the local government. ${ }^{44}$ The EPA Regulatory power also includes establishing industry-specific emission standards to construct new pollution sources such as factories and other facilities, where they are required to meet standards and adopt as low emission technologies as possible. In addition, under the Clean Air Act, the EPA has the power to regulate most motorized vehicles, including the power to impose testing and certification requirements for engines, as well as specific fuel formulations. This power is broad enough that it has been able to reduce the level of pollution. As stated by Currie and Walker, with the consistent monitoring by EPA, The Air quality in the United States has improved dramatically over the past 50 years. ${ }^{45}$

As the embodiment of the "polluter pays" principle in environmental law, EPA gave authority to impose a sanction in the form of a fine to the polluters. The EPA fines firms for violating US environmental laws or emitting noxious pollutants into the air, water, or land, which can negatively affect the

\footnotetext{
${ }^{41}$ Environmental Protection Agency (EPA), "The Origin of EPA," Environmental Protection Agency, 2020, https://www.epa.gov/history/origins-epa.

${ }^{42}$ Funk and Seamon, Administrative Law: Examples and Explanations.

${ }^{43}$ Environmental Protection Agency (EPA), "Laws and Executive Orders," Environmental Protection Agency, 2020, https://www.epa.gov/laws-regulations/laws-and-executive-orders.

${ }^{44}$ Janet Currie and Reed Walker, "What Do Economists Have to Say about the Clean Air Act 50 Years after the Establishment of the Environmental Protection Agency?," Journal of Economic Perspectives 33, no. 4 (2019): 3-26, https://doi.org/10.1257/jep.33.4.3.

45 Nathaniel O. Keohane, Erin T. Mansur, and Andrey Voynov, "Averting Regulatory Enforcement: Evidence from New Source Review," Journal of Economics \& Management Strategy 18, no. 1 (2009): 75-104, https://doi.org/10.1111/j.1530-9134.2009.00208.x. 
community. Based on the research by Romero et al., ${ }^{46}$ This shows that the legal sanctions and fines issued by the EPA have a significant influence in encouraging companies to behave more responsibly in environmental matters. There is also the fact that the larger an activity or company, the greater the penalty received; thus, the size of the polluting company determines the amount of the fine received.

\section{Recommendation For Policy and Supervision}

The United Nations has merged Millennium Development Goals into Sustainable Development Goals and published the 2030 Sustainable Development Agenda. Goal No.16 has stressed the need to "substantially reduce corruption and bribery; promote the rule of law; develop effective, accountable, and transparent institutions; ensure responsive, inclusive, participatory, and representative decision-making at all levels; strengthen relevant national institutions, and ensure equal access to justice for all". ${ }^{47}$ Under the UN SDGs, UNDP's Global Anti-Corruption Initiatives (GAIN) (2014-2017) has adopted the strategy as a lead role in strengthening UNDP's policy and program, among them are: ${ }^{48}$ Expanding the political and normative agenda on anti-corruption by integrating anti-corruption in service delivery; Strengthening state/institutional capacities to prevent and combat corruption, and improving institutional effectiveness of anti-corruption initiatives and monitoring their results.

Refers to the policy lines above, we can see that there is an emphasis on the role of the government through state institutional reform. This is understandable, given that a simple bureaucracy, qualified and independent government apparatus and government credibility are important factors that determine a successful environmental sustainability program. ${ }^{49}$ The problems related to environmental, including environmental corruption, could be effectively overcome if government institutions work in a professional, transparent, accountable, and full of integrity. ${ }^{50}$ To The study conducted by

\footnotetext{
${ }^{46}$ Jorge A. Romero, Martin Freedman, and Neale G. O'Connor, "The Impact of Environmental Protection Agency Penalties on Financial Performance," Business Strategy and the Environment 27, no. 8 (2018): 1733-40, https://doi.org/10.1002/bse.2239.

${ }^{47}$ United Nations, "Transforming Our World: The 2030 Agenda for Sustainable Development," United Nations, 2018, http://www.un.org/pga/wpcontent/uploads/sites/3/2015/08/120815_outcome-document-of-Summit-for-adoption-of-thepost2015-development-agenda.pdf.

48 Biswajit Bandyopadhyay, "Indian Perspective Of Anti-Corruption Institutions For Combating Corruption In Sustainable Development: A Scorecard," Delhi Business Review 19, no. 1 (2018): 85-106, https://doi.org/10.51768/dbr.v19i1.191201815.

49 Isabel Gallego-Alvarez et al., "Environmental Performance in Countries Worldwide: Determinant Factors and Multivariate Analysis," Sustainability 6, no. 11 (2014): 7807-32, https://doi.org/10.3390/su6117807.

50 Andreas Duit, "Understanding Environmental Performance of States: An InstitutionCentered Approach and Some Difficulties" (Gothenburg, 2005).
} 
Duit ${ }^{51}$ Has been proven that good public governance practice in governmental institutions has a positive implication to environmental sustainability performance. The higher the country's public governance, the higher the environmental sustainability performance that country will be.

Based on the description above and the analysis on the patterns of environmental corruption and its problem gaps, a number of recommendations for environmental corruption policy and supervision in Indonesia can be formulated as follows: First, there needs to be institutional and managerial reform in the environmental sector through the formation of the independent agency. The choice to form a new independent agency was based on considering that this type of institution has a number of advantages over ordinary state institutions such as executive agencies or ministries. The multimember leadership makes it difficult to intervene, the staggered term of office that guarantees independence for members, and the leaders from political interference. So that in general, the independent agency has an institutional design that guarantees and protects the agency against the possibility of intervention and the strong desire for corruption, collusion, and nepotism. There are other options for downsizing state institutions by forming new divisions within existing independent agencies, such as in the Corruption Eradication Commission (KPK). However, it is felt that this will not be optimal because the KPK is an institution whose focus is not only on the environment but on corruption in general.

Meanwhile, the current situation requires a regulatory and supervisory authority in the environmental sector that is independent and free from political influence. Second, the new independent agency in the environmental sector must be accompanied by a delegation of authority from the government or laws to formulate and implement policies in environmental protection, management, and monitoring. As well as giving the authority to investigate and impose sanctions and fines similar to EPA in the United States.

\section{Figure 2. Environmental Corruption Policy Model}

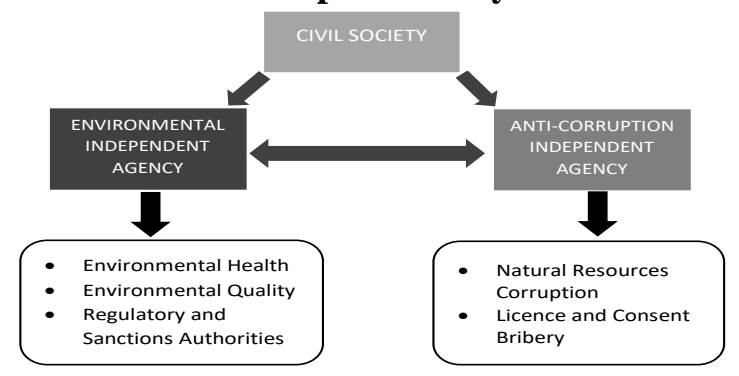

Source: Author's result, 2020.

\footnotetext{
${ }^{51}$ Sofik Handoyo, "The Role of Public Governance in Environmental Sustainability," Jurnal Ilmiah Peuradeun 6, no. 2 (2018): 161-78, https://doi.org/10.26811/peuradeun.v6i2.255. 
The Third recommendation is compiling a national strategic program in the form of work synergy between independent agencies in the environmental sector and the anti-corruption agency (KPK), with the participation of civil society in eradicating environmental corruption. Synergy and collaboration are essential aspects in eradicating corruption. This is necessary to avoid different perceptions, overlapping authority, and sectoral egos in carrying out tasks in the field. With this policy and supervision model, it is assumed to maximize efforts to eradicate environmental corruption. It is hoped that environmental policies and supervision in independent institutions can be carried out more transparently and accountably. With guarantees of independence both structurally and functionally, independent institutions are deemed more appropriate to implement policies and monitor an environment prone to corrupt practices. The design of institutional independence can better guarantee the actors to carry out their duties professionally and without intervention.

\section{Conclusion}

Several environmental and anti-corruption policies at the global level have emphasized the importance of the state's role through its institutions in maintaining environmental quality and eradicating corruption. The old structure of state institutions and their fat bureaucracy has become an opening for environmental corruption. A corrupt bureaucracy will lead to weak environmental policies and supervision, which will result in more state losses and environmental damage. Based on this, it is necessary to formulate policies through institutional reform and management of the environmental sector by forming an independent agency. The design of an independent agency can guarantee functional and structural independence, which is expected to protect its actors from conflicts of interest and power intervention. Thus, it can overcome the corrupt culture in the old bureaucracy. Also, there needs to be synergy between independent agencies in the environment and the anticorruption sector by involving civil society to maximize efforts to eradicate environmental corruption.

\section{References}

(EPA), Environmental Protection Agency. "Laws and Executive Orders." Environmental Protection Agency, 2020. https://www.epa.gov/lawsregulations/laws-and-executive-orders.

(OECD), Organization for Economic Co-operation and Development. Corruption: A Glossary of International Criminal Standards. Paris: OECD, 2007.

Ackerman, Bruce. "The New Separation of Powers." Harvard Law Review 113, no. 3 (2000): 633-729. https://doi.org/10.2307/1342286.

Ackerman, Susan Rose. Korupsi Dan Pemerintahan Sebab Akibat Dan 
Reformasi. Jakarta: Pustaka Sinar Harapan, 2006.

Asshiddiqie, Jimly. Pengantar Ilmu Hukum Tata Negara. 5th ed. Jakarta: PT Raja Grafindo Persada, 2015.

Bandyopadhyay, Biswajit. "Indian Perspective Of Anti-Corruption

Institutions For Combating Corruption In Sustainable Development: A

Scorecard." Delhi Business Review 19, no. 1 (2018): 85-106. https://doi.org/10.51768/dbr.v19i1.191201815.

Bima, Muh Rinaldy, and Rizki Ramadani. "Position of Supervisory Board

Organ and Its Implications for the Institutional Corruption Eradication Commission." Law Reform 16, no. 2 (2020): 179-97. https://doi.org/10.14710/lr.v16i2.33770.

Currie, Janet, and Reed Walker. "What Do Economists Have to Say about the Clean Air Act 50 Years after the Establishment of the Environmental Protection Agency?" Journal of Economic Perspectives 33, no. 4 (2019): 3-26. https://doi.org/10.1257/jep.33.4.3.

Damania, Richard, Per G. Fredriksson, and John A. List. "Trade Liberalization, Corruption, and Environmental Policy Formation: Theory and Evidence." Journal of Environmental Economics and Management 46, no. 3 (2003): 490-512. https://doi.org/10.1016/s00950696(03)00025-1.

Duit, Andreas. "Understanding Environmental Performance of States: An Institution-Centered Approach and Some Difficulties." Gothenburg, 2005.

Environmental Protection Agency (EPA). "The Origin of EPA." Environmental Protection Agency, 2020. https://www.epa.gov/history/origins-epa.

Funk, William F., and Richard H. Seamon. Administrative Law: Examples and Explanations. New York: Aspen Publishers, 2009.

Gallego-Alvarez, Isabel, Vicente-Galindo, Galindo-Villardón, and Miguel Rodríguez-Rosa. "Environmental Performance in Countries Worldwide: Determinant Factors and Multivariate Analysis." Sustainability 6, no. 11 (2014): 7807-32. https://doi.org/10.3390/su6117807.

Gilardi, Fabrizio. Delegation in the Regulatory State: Independent Regulatory Agencies in Western Europe. Cheltenham: Edward Elgar Publishing, 2009.

Hadi, Kisno. "Korupsi Birokrasi Pelayanan Publik Di Era Otonomi Daerah." Jurnal Penelitian Politik 7, no. 1 (2016): 51-70. https://doi.org/10.14203/jpp.v7i1.512.

Handoyo, Sofik. "The Role of Public Governance in Environmental Sustainability." Jurnal Ilmiah Peuradeun 6, no. 2 (2018): 161-78. https://doi.org/10.26811/peuradeun.v6i2.255.

Handoyo, Sofik, and Fury Khristianty Fitriyah. "Control of Corruption, Regulatory Quality, Political Stability, and Environmental Sustainability: A Cross-National Analysis." Journal of Accounting 
Auditing and Business 1, no. 2 (2018): 28-38. https://doi.org/10.24198/jaab.v1i2.18344.

Heyin Chen, Yu Hao, Jingwei Li, and Xiaojie Song. "The Impact of Environmental Regulation, Shadow Economy, and Corruption on Environmental Quality: Theory and Empirical Evidence from China." Journal of Cleaner Production 195 (2018): 200-214. https://doi.org/10.1016/j.jclepro.2018.05.206.

Husin, Sukanda, and Hilaire Tegnan. "Corruption Eradication within the Protection of the Environment in Indonesia." Asian Journal of Water, Environment and Pollution 14, no. 4 (2017): 99-108. https://doi.org/10.3233/AJW-170040.

Index, Environmental Performance. "Global Metrics for the Environment: Ranking Country Performance on Sustainability Issues." Yale Center for $\begin{array}{llll}\text { Environmental Law } \quad \text { \& } & 2020 .\end{array}$ https://epi.yale.edu/downloads/epipolicymakersummaryr11.pdf.

Keohane, Nathaniel O., Erin T. Mansur, and Andrey Voynov. "Averting Regulatory Enforcement: Evidence from New Source Review.” Journal of Economics \& Management Strategy 18, no. 1 (2009): 75-104. https://doi.org/10.1111/j.1530-9134.2009.00208.x.

Komara, Indra. "Survei LSI Polisi, Pengadilan Dan PNS Instansi Paling Korup.” Detiknews, 2018. https://news.detik.com/berita/d4227042/survei-lsi-polisi-pengadilan-dan-pns-instansi-paling-korup.

Komisi Pemberantasan Korupsi (KPK). "Laporan Akuntabilitas Kinerja KPK 2014.” Jakarta, 2014.

Korupsi, Komisi Pemberantasan. "Laporan Tahunan Komisi Pemberantasan Korupsi Tahun 2014.” Jakarta, 2014.

Mehlum, Halvor, Karl Moene, and Ragnar Torvik. "Cursed by Resources or Institutions?" World Economy 29, no. 8 (2006): 1117-31. https://doi.org/10.1111/j.1467-9701.2006.00808.x.

Mény, Yves, and Andrew Knapp. Government and Politics in Western Europe: Britain, France, Italy, Germany. Oxford: Oxford University Press, 1993.

Muslihudin Muslihudin, Eko Hendarto, Rin Rostikawati, Rili Windiasih, and Tyas Retno Wulan. "Relationship between Environmental Damage and Corruption Cases in Indonesia." E3S Web of Conferences 73 (2018): 15. https://doi.org/10.1051/e3sconf/20187302011.

Nagara, Grahat, Belinda Sahadati Amri, Dian Patria, and Farid Andhika. "Persoalan Struktural Dalam Politik Penegakan Hukum Sumber Daya Alam Dan Lingkungan Hidup." Integritas: Jurnal Antikorupsi 5, no. 22 (2020): 65-74. https://doi.org/10.32697/integritas.v5i2-2.483.

Nations, United. "Transforming Our World: The 2030 Agenda for Sustainable Development." United Nations, 2018. http:/www.un.org/pga/wpcontent/uploads/sites/3/2015/08/120815_outcome-document-ofSummit-for-adoption-of-the-post2015-development-agenda.pdf. 
Pencegahan), Direktorat Penelitian dan Pengembangan (Kedeputian Bidang. "Mencegah Kerugian Negara Di Sektor Kehutanan Sebuah Kajian Tentang Sistem Penerimaan Negara Bukan Pajak Dan Penatausahaan Kayu.” Komisi Pemberantasan Korupsi, 2015. https://acch.kpk.go.id/images/tema/litbang/pengkajian/pdf/Laporan-

PNBP-Kehutanan-KPK-report-web.pdf.

Purnomo, Herry, David Gaveau, Jacob Phelps, and Rachel Carmenta. "Politik Ekonomi Kebakaran Hutan Dan Asap Di Indonesia." Center for International Forestry Research, 2015. https://forestsnews.cifor.org/30905/politik-ekonomi-kebakaran-hutandan-asap-di-indonesia?fnl=en.

Rachman, Dylan Aprialdo. "Kerugian Negara Akibat Korupsi Capai Rp. 929 Triliun.” Kompas.com, 2019.

Ramadani, Rizki. "Lembaga Negara Independen Di Indonesia Dalam Perspektif Konsep Independent Regulatory Agencies." Jurnal Hukum Ius Quia Iustum 27, no. 11 (2020): 169-92. https://doi.org/10.20885/iustum.vol27.iss1.art9.

Ramadani, Rizki, and Andika Prawira Buana. "The Needed but Unwanted Independent Regulatory Agencies: Questioning Their Legitimacy and Control in Indonesia." In Proceedings of the 2nd International Conference of Law, Government and Social Justice (ICOLGAS 2020), 674-84. Dordrecht: Atlantis Press, 2020. https://doi.org/10.2991/assehr.k.201209.351.

Ramadani, Rizki, and Moch Andry Wikra Wardhana Mamonto. "Legalitas Sanksi Pidana Pencabutan Hak Politik Bagi Terpidana Korupsi: Perspektif Hak Asasi Manusia." Petitum 7, no. 2 (2019): 63-71. https://doi.org/10.33096/substantivejustice.v1i2.18.

Rasad, Fauziah. "Korupsi Dan Hak Asasi Manusia Dalam Sektor Kehutanan." Jurnal HAM 9, no. 2 (2018): $121-38$. https://doi.org/10.30641/ham.2018.9.121-138.

Romero, Jorge A., Martin Freedman, and Neale G. O'Connor. "The Impact of Environmental Protection Agency Penalties on Financial Performance." Business Strategy and the Environment 27, no. 8 (2018): 1733-40. https://doi.org/10.1002/bse.2239.

Shacklock, Arthur, Fredrik Galtung, and Charles Sampford. Measuring Corruption. 1st ed. London: Routledge, 2016.

Sinha, Avik, Monika Gupta, Muhammad Shahbaz, and Tuhin Sengupta. "Impact of Corruption in the Public Sector on Environmental Quality: Implications for Sustainability in BRICS and next 11 Countries." Journal of Cleaner Production 232 (2019): 1379-93. https://doi.org/10.1016/j.jclepro.2019.06.066.

Suyatmiko, Wawan, and Lvin Nicola. "Inisiatif Penguatan Lembaga Antikorupsi Indonesia: Komisi Pemberantasan Korupsi 2015-2019." Tranparancy International, 2018. https://ti.or.id/wp- 
content/uploads/2019/07/FINAL-Bahasa-ACA-AssessmentReport_TII.pdf.

Tacconi, Luca, and David Aled Williams. "Corruption and Anti-Corruption in Environmental and Resource Management." Annual Review of Environment and Resources 45 (2020): 305-29. https://doi.org/10.1146/annurev-environ-012320-083949.

Tsia, Wardhany Tsa. "Crowded Criticism Corruption Perception Index Score in Indonesia Is Dropping." Voice Of Indonesia, 2021. https://voi.id/en/berita/29720/crowded-criticism-corruption-perceptionindex-score-in-indonesia-is-dropping.

Verhoest, Koen, Paul Roness, Bram Verschuere, Kristin Rubecksen, and Muiris MacCarthaigh. Autonomy and Control of State Agencies: Comparing States and Agencies. 1st ed. London: Palgrave Macmillan, 2010. https://doi.org/10.1057/9780230277274.

Watch, Human Rights. Indonesia; "Wild Money"; The Human Rights Consequences of Illegal Logging and Corruption in Indonesia's Forestry Sector. New York: HRW, 2009.

Winbourne, Svetlana. "Corruption and the Environment." Washington, D.C., 2020.

Yuwanto, Listyo. "Kinerja Penanganan Tindak Pidana Korupsi Sumber Daya Alam Dan Kcayaan Terhadap Komisi Pemberantasan Korupsi." Jurnal Integritas 2, no. 1 (2016). https://doi.org/10.32697/integritas.v2i1.137.

\section{Grants}

We would like to thank the Research and Development Institute of Universitas Muslim Indonesia (LP2S UMI) and Faculty of Law UMI for financial support and review suggestions for this research. 
